\title{
Interfacial Staining of a Phase-Separated Block Copolymer with
}

\author{
Ruthenium Tetroxide
}

Yishan Wang, Neil Coombs, Ayse Turak, Zheng-Hong Lu, Ian Manners ${ }^{*}$, Mitchell A. Winnik ${ }^{*}$

\section{Supporting Information}
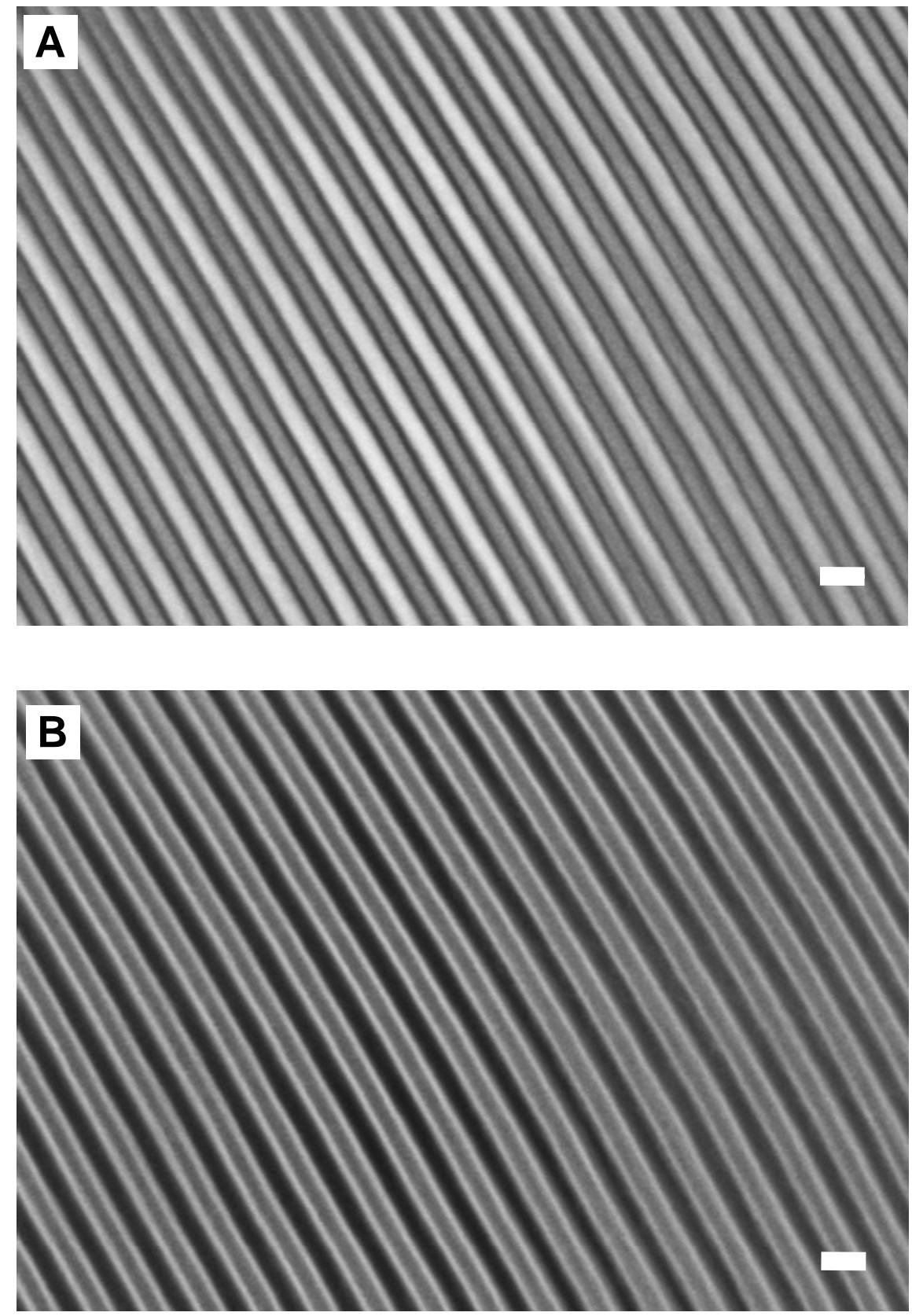

Fig S1. (a) bright field TEM image and (b) annular dark field TEM image of PFDMS $_{105}$-b-PDMS ${ }_{300}$ thin section after $\mathrm{RuO}_{4}$ staining; scale bar: $30 \mathrm{~nm}$. 